\title{
The influence of inclusion of either an antibiotic or a probiotic in the diet on the development of digestive enzyme activity in the pig
}

\author{
BY G. K. COLLINGTON, D. S. PARKER AND D. G. ARMSTRONG \\ Department of Agricultural Biochemistry and Nutrition, University of Newcastle upon Tyne, \\ Newcastle Upon Tyne NEI $7 R U$
}

(Received 29 November 1989 - Accepted 14 February 1990)

\begin{abstract}
The aim of the present experiment was to determine the influence of either probiotic or antibiotic inclusion in the diets of pigs from birth on the development of enzyme activity in the small intestine. Pigs were fed on creep feed and grower diets containing either a probiotic, an antibiotic or no added growth promoter. At 7, 17, 42 and $80 \mathrm{~d}$ of age pigs from each treatment group were sampled to investigate the development of carbohydrase and peptidase activity in the mucosa at five sites along the small intestine. Inclusion of either the probiotic or antibiotic had a significant effect on the development of sucrase (sucrose $\alpha$-D-glucohydrolase; $E C$ 3.2.1.48), lactase ( $\beta$-D-galactoside galactohydrolase; $E C$ 3.2.1.23) and tripeptidase $(E C 3.4 .11 .4)$ activities before weaning but had no effect on depeptidase (EC 3.14.13.11) activity. The study of the distribution of enzyme activity along the small intestine showed significant differences between the proximal and distal sections associated with weaning.
\end{abstract}

Antibiotics: Probiotics: Intestinal enzyme activity: Piglet

It is well established that the manipulation of the intestinal microflora in both ruminant and non-ruminant species has a significant effect on growth rate and the efficiency of feed utilization (for reviews see Armstrong, 1984, 1986). While the influence that antimicrobial agents in feed have on aspects of rumen function have been well documented, the effect of changes in the microbial population of the small and large intestine are less well understood. A number of antimicrobial compounds, including dietary copper (Braude, 1967), have been shown to be effective in improving growth rates in pigs, and their mode of action has been attributed to factors associated with alteration in the balance of microbial species in the small intestine. These include changes in the structure of the intestinal wall, reduction in the production of toxic compounds such as ammonia or amines, and a reduction in the utilization of essential nutrients by bacterial species (Visek, 1978). Manipulation of the microbial flora in the intestine can also be achieved by the establishment of a specific group of bacterial species within the tract following oral dosing of the animal, the use of so-called 'probiotic' preparations. This method is suggested to be particularly beneficial in reducing the chances of establishing a pathogenic flora within the digestive tract at times of stress and was first proposed by Metchnikoff (1908). Changes in intestinal flora as a result of a range of stress factors have been shown in a number of animal species (Tannock, 1983).

The objective of the present study was to investigate the effect of either an antibiotic feed additive or a probiotic preparation on the growth of pigs from birth to $80 \mathrm{~d}$ of age, and of these treatments on the development of digestive enzyme activity in the mucosa of the small intestine. The enzymes studied were sucrase (sucrose $\alpha$-D-glucohydrolase; EC 3.2 1.48), lactase ( $\beta$-D-galactoside galactohydrolase; $E C$ 3.2.1.23), dipeptidase (EC 3.14.13.11; substrate L-leucylglycine) and tripeptidase (EC 3.4.11.4; substrate L-leucylglycylglycine). 
Of these, the carbohydrases are located in the brush border membrane of the enterocyte cell (Schmitz et al. 1973) and the dipeptidase in the cytosol (Peters, 1970, 1977). Tripeptidase activity is located primarily, although not exclusively, in the brush border region of the cell (Peters, 1970, 1977). The findings relating to the growth rates obtained in the present experiment have been published (Collington et al. 1988).

\section{MATERIALS AND METHODS}

\section{Treatments}

The trial consisted of three treatments : (1) basal diet containing no added growth promoter and with $\mathrm{Cu}$ at nutritional levels; (2) basal diet and antibiotic growth promoter tylosin (Elanco Products Ltd, Basingstoke, Hants), a macrolide antibiotic isolated from Streptomyces fradiae and active against Gram + ve organisms (Brander, 1986), at $40 \mathrm{mg} / \mathrm{kg}$; (3) basal diet and probiotic preparation Probios ${ }^{\mathbb{R}}$ (Pioneer Hi-Bred International Ltd, Johnston, Iowa, USA) administered as an oral gel $24 \mathrm{~h}$ after birth ( $1 \mathrm{~g})$, again at $7 \mathrm{~d}$ of age $(1 \mathrm{~g})$ and at weaning $(2 \mathrm{~g})$. The probiotic was included as granules in both the creep feed and follow-on diet at $1 \mathrm{~kg}$ /tonne. Both forms of the probiotic contained $10^{7}$ colonyforming units/g and comprised a mixture of multiple strains of Lactobacillus plantarum, Lactobacillus acidophilus, Lactobacillus casei and Streptococcus faecium.

\section{Experimental animals}

The present study was carried out on litters of cross-bred (Large White/Landrace/Duroc) piglets, and because of space limitations in the farrowing house was organized in three phases with two of the treatments represented in each phase. All four sows in each phase farrowed within $48 \mathrm{~h}$ of each other and there was a period of 2 weeks between phases. Sows were paired according to farrowing date, and within each pair of sows each litter was split into two, keeping the sex ratio equal in each half. Each of the sows, therefore, had a cohort of piglets half of her own and half cross-fostered. Runts were included in the cross-fostering process. The two treatments represented in a particular phase were randomly allocated to the four cohorts such that within each pair of sows one cohort was allocated to each treatment. Whilst in the farrowing house all cohorts were penned individually, and following weaning animals were penned in treatment groups with the two cohorts from each treatment in each pen. At all times precautions were taken to avoid crosscontamination between treatment groups.

\section{Diets and feeding}

The creep feed and the follow-on ration were formulated to provide respectively 253 and $200 \mathrm{~g}$ crude protein $/ \mathrm{kg}$ (nitrogen $\times 6.25$ ) with lysine contents of 0.133 and $0.11 \mathrm{~g} / \mathrm{kg}$. The diet formulations and relevant chemical analyses are shown in Table 1 . Both diets contained $\mathrm{Cu}$ at nutritional levels $(20-70 \mathrm{mg} / \mathrm{kg})$. Litters were offered creep feed from $7 \mathrm{~d}$ of age and piglets were weaned from the farrowing house to flat-deck housing at $21 \mathrm{~d}$ of age. All pigs were weighed at weekly intervals.

\section{Tissue sampling}

On each of days 7, 17, 42 and 80 , one pig was randomly selected from each cohort for tissue sampling. At these times an attempt was made to balance for sex and for natural/foster mother. This process resulted in four pigs per treatment being sampled at each of the four ages. In order to obtain tissues that had not been subjected to mucosal shedding (Badaway et al. 1957), animals were restrained and anaesthetized with Halothane $(40 \mathrm{ml} / \mathrm{l})-$ oxygen-nitrous oxide administered via an open mask. Following laparotomy the animals 
Table 1. Components of creep feed and follow-on diet $(\mathrm{g} / \mathrm{kg}$ fresh weight) and dietary nutrients

\begin{tabular}{lcc}
\hline \hline & Creep feed & Follow-on \\
\hline Wheat & 320 & 250 \\
Barley & 250 & 470 \\
Dry skimmed milk & 210 & 10 \\
Soya-bean meal & 150 & 150 \\
Fishmeal & 55 & 100 \\
Vitamin-mineral mix & 15 & 20 \\
Dry matter (DM ; $/ \mathrm{kg})$ & $921 \cdot 4$ & $915 \cdot 9$ \\
Ash (g/kg DM) & $52 \cdot 26$ & $59 \cdot 92$ \\
Oil (g/kg DM) & $20 \cdot 68$ & $18 \cdot 68$ \\
Crude protein (nitrogen $\times 6 \cdot 25 ; \mathrm{g} / \mathrm{kg} \mathrm{DM})$ & $245 \cdot 00$ & 233.00 \\
Gross energy (MJ/kg DM) & $20 \cdot 24$ & $20 \cdot 24$ \\
Copper (mg/kg DM) & $20 \cdot 90$ & $68 \cdot 30$ \\
\hline
\end{tabular}

were killed by an injection of sodium barbitone $(1 \mathrm{ml} / \mathrm{kg}$ body-weight; Euthatal, May and Baker Ltd, Dagenham, Essex) given via the portal vein. The gastrointestinal tract was removed immediately and the small intestine freed from the mesentery. Samples of mucosal tissue were isolated from $50 \mathrm{~mm}$ lengths of intestine taken at sites $0.05,0.1,0.3,0.6$ and 0.8 along the small intestine. Intestinal sections were opened longitudinally, rinsed with icecold saline ( $9 \mathrm{~g}$ sodium chloride/l), blotted dry and placed on a chilled porcelain tile. Mucosa was scraped from the muscle layer using a microscope slide (McCarthy \& Kim, 1973), wrapped in tin foil and snap frozen in liquid $N_{2}$ before being stored at $-70^{\circ}$.

\section{Chemicals}

All biochemicals were obtained from Sigma Chemical Co., Poole, Dorset.

\section{Enzyme assays}

All assays were carried out on homogenates of mucosal tissue obtained by thawing approximately $1 \mathrm{~g}$ tissue and homogenizing it in $15 \mathrm{ml}$ of a solution containing $50 \mathrm{~mm}$ mannitol and $2 \mathrm{~mm}$-Tris-hydrochloride ( $\mathrm{pH} \mathrm{7 \cdot 1)}$ using twelve strokes of a teflon-glass homogenizer. The homogenate was made up to $25 \mathrm{ml}$ with the same buffer and portions stored at $-70^{\circ}$ before being assayed.

Sucrase and lactase were assayed by the method of Dahlqvist (1964), and dipeptidase (substrate L-leucylglycine) and tripeptidase (substrate L-leucylglycylglycine) by that of Nicholson \& Kim (1975). In these assays the hydrolysis of the di- or tripeptide to release amino acids is linked to oxidation of the leucine by L-amino acid oxidase $(E C$ 1.4.3.2) with the resulting formation of hydrogen peroxide. Oxidation of $o$-dianisidine by hydrogen peroxide following the action of peroxidase $(E C 1.11 .1 .7)$ results in a specific end-point to the reaction with an absorbance at $530 \mathrm{~nm}$. In using the substrates leucylglycine and leucylglycylglycine, the activities of the two hydrolases could be distinguished from one another. The end product of the tripeptidase assay, i.e. glycylglycine, if hydrolysed by dipeptidase activity does not react in the assay system. All assays were adjusted to ensure linear rates of reaction over time with volume of homogenate added and substrate concentration.

\section{Statistical analysis}

The data were analysed using the GLM statistical package (Baker \& Nelder, 1978) which allows for the sequential fitting of all factors which may affect the variable being analysed. 
Table 2. Sources of variation and degrees of freedom for analysis of data for enzyme activity summed across all intestinal sites for pigs at 7,17,42 and $80 \mathrm{~d}$ of age

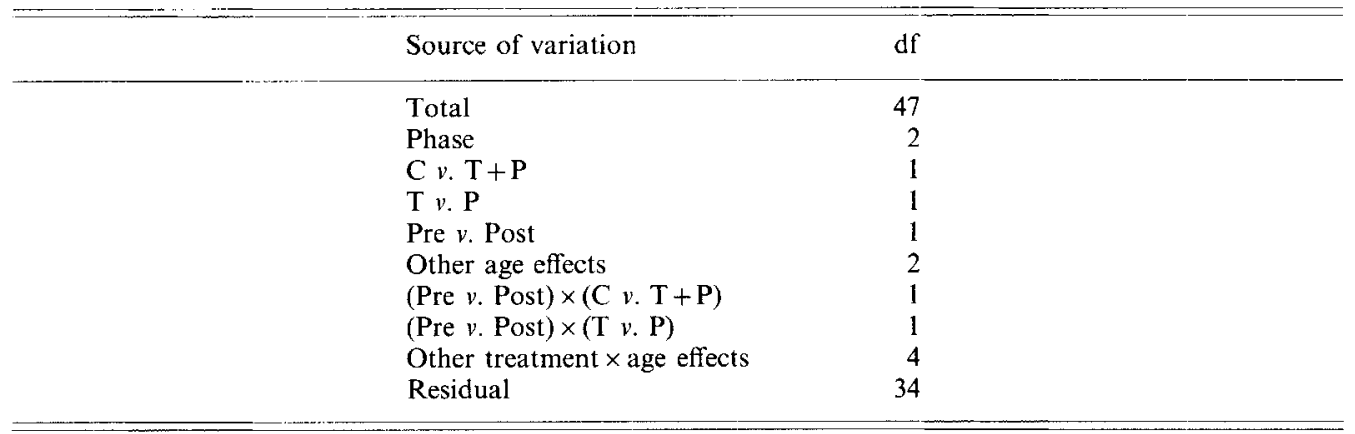

Treatment: C, basal diet; T, basal diet +tylosin $(40 \mathrm{mg} / \mathrm{kg}) ; \mathrm{P}$, basal diet + Probios; age: Pre, preweaning $(7 \mathrm{~d}+17 \mathrm{~d})$; Post, post-weaning $(42 \mathrm{~d}+80 \mathrm{~d})$.

Table 3. Sources of variation and degrees of freedom for analysis of effects of treatment and intestinal site on enzyme activity for pigs at 7,17,42 and $80 \mathrm{~d}$ of age

\begin{tabular}{lr} 
Source of variation & $\mathrm{d}$ \\
\hline Total & 59 \\
Phase & 2 \\
C $v . \mathrm{T}+\mathrm{P}$ & 1 \\
T $v$. P & 1 \\
Prox $v$. Dist & 1 \\
Other site effects & 3 \\
(Prox $v$. Dist $) \times(\mathrm{C} v . \mathrm{T}+\mathrm{P})$ & 1 \\
(Prox $v$. Dist $) \times(\mathrm{T} v . \mathrm{P})$ & 1 \\
Other treatment $\times$ site effects & 6 \\
Residual & 43 \\
\hline
\end{tabular}

Treatment : C, basal diet; T, basal diet +tylosin $(40 \mathrm{mg} / \mathrm{kg}) ; \mathrm{P}$, basal diet + Probios; site: Prox, proximal sites $(0 \cdot 05,0 \cdot 10,0 \cdot 30)$; Dist, distal sites $(0 \cdot 60,0 \cdot 80)$.

The initial analysis was carried out across all ages studied with the summed data for all sites within the intestine and was designed to test whether there were any significant effects of age and treatment or the 'blocking' factors phase, sex and mothering. The latter factor was included to identify effects that might have arisen due to the fact that some pigs were reared on a foster rather than a natural mother. In addition the interactions of all the factors were fitted and the residual sums of squares used to calculate the error term against which all the null hypotheses were tested. As a result of this initial analysis it was determined that the factors sex and mothering had no significant effects on any of the enzyme activities measured and the analysis was consolidated to determine the effects of phase, treatment and age and treatment $\times$ age interactions. Phase was retained in the analysis as it was found to be significant in a number of cases although this may have been related to the unbalanced nature of the experimental design (not all treatments were included in each phase) rather than any biological effect. The analysis also included splitting the age effect into pre- and post-weaning $(7+17 \mathrm{~d} v .42+80 \mathrm{~d})$ and the treatment effect into control $v$. tylosin + Probios and tylosin $v$. Probios. An outline of the analysis of variance table is shown in Table 2.

Data analysed at each of the four ages of pig studied were expanded to include values for each of the five intestinal sites. The factors were fitted in the analysis as phase, 


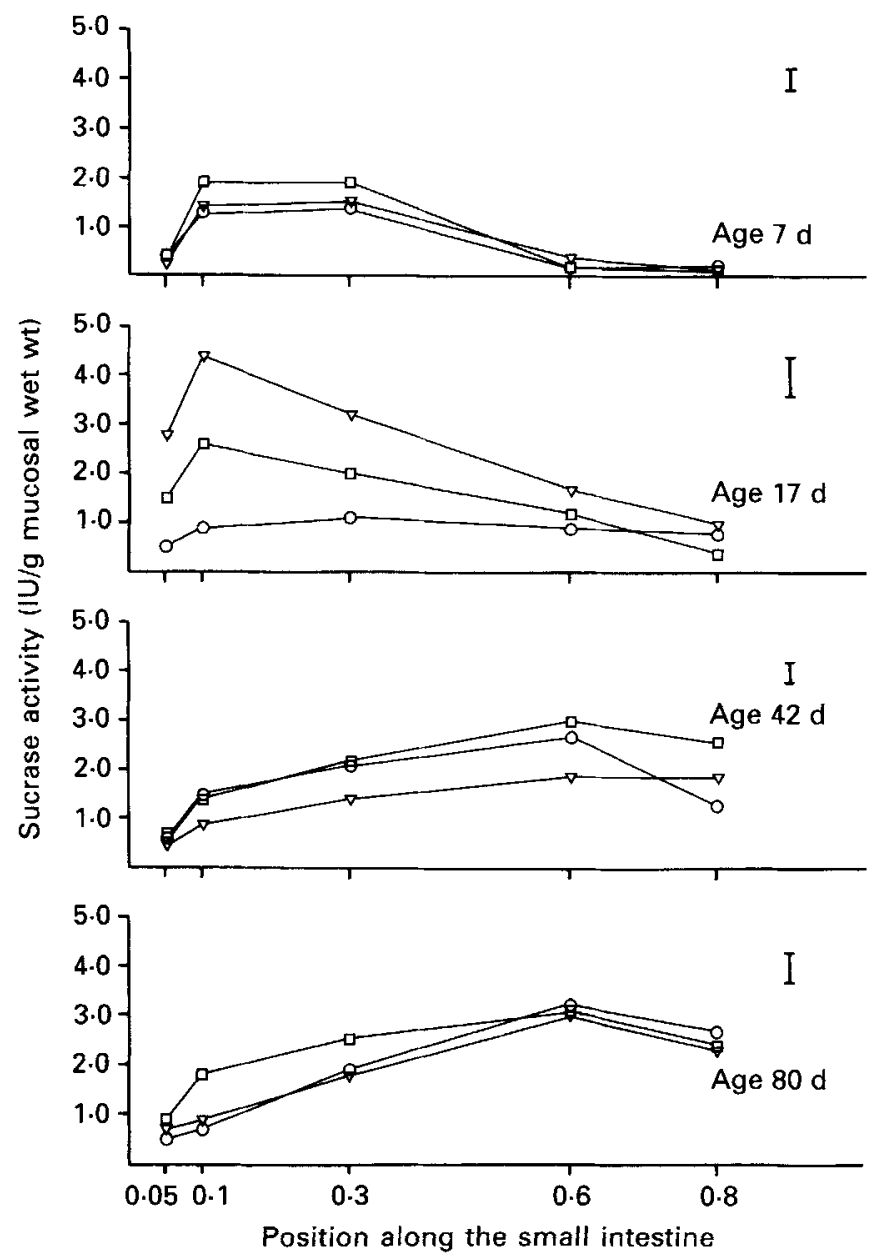

Fig. 1. The distribution of sucrase $(E C$ 3 2.1 .48$)$ activity (IU/g mucosal wet weight) in the mucosal tissue of the small intestine of pigs of different ages. Points are means, with their pooled standard errors represented by vertical bars, for four replicates. Treatments : $(O)$, control; $(\square)$, probiotic; $(\nabla)$, tylosin; for details of dietary treatments, see Table 1 and p. 60 .

treatment, intestinal site and treatment $x$ intestinal site and subsequently the effect of treatment divided to consider the analysis of control $v$. tylosin + Probios and tylosin $v$. Probios. Intestinal site was also re-analysed to consider the effect of proximal $(0 \cdot 05,0 \cdot 10$ and 0.30$)$ sites $v$. distal $(0.60$ and 0.80$)$ sites. An outline of the analysis of variance table is shown in Table 3.

\section{RESULTS}

Mean values for the activity of each of the enzymes studied at five sites along the small intestine and at four ages of the pig are shown in Figs. 1-4. Analysis of the data across all ages and based on summed activity at sites along the small intestine (Table 4) showed that there was no significant effect of treatments on enzyme activity. There was, however, a significant effect of age, the activities of lactase and dipeptidase being higher $(P<0.001)$ in 

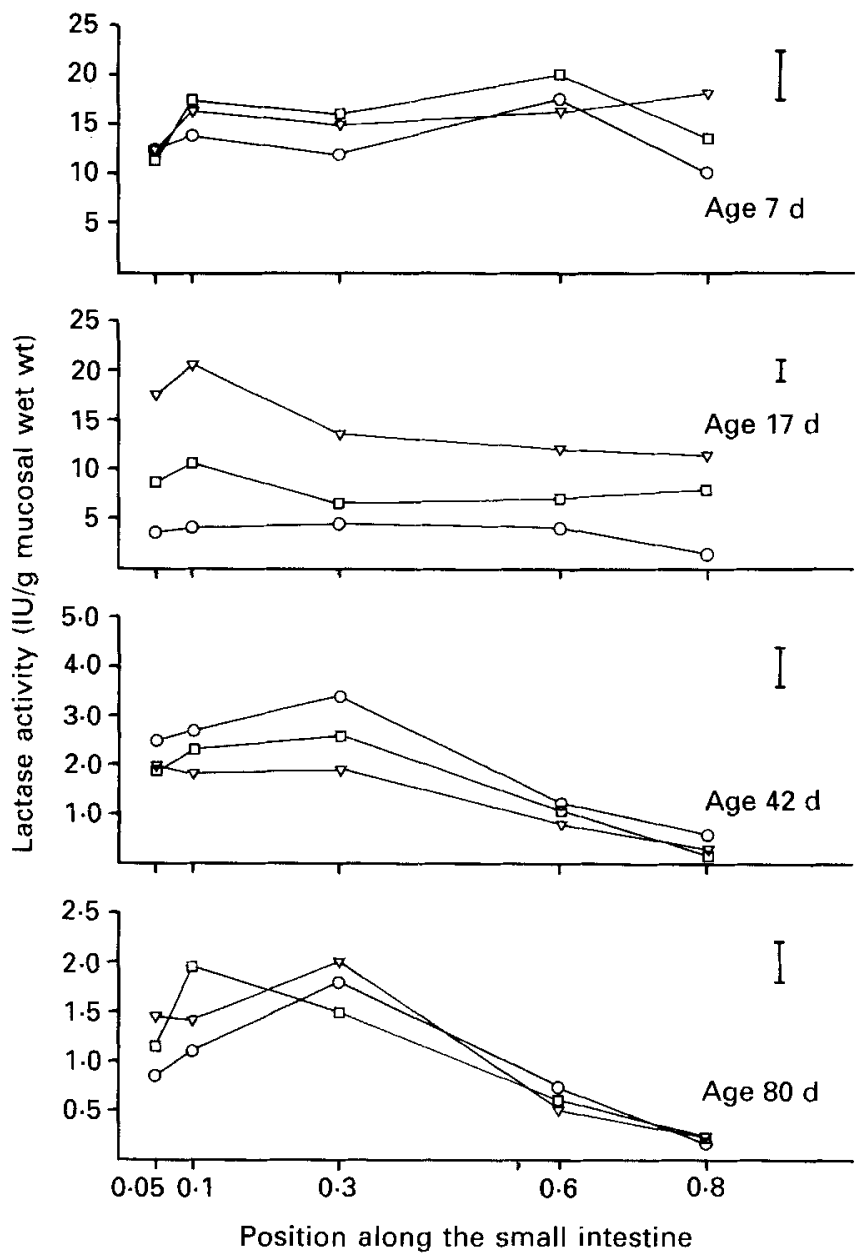

Fig. 2. The distribution of lactase (EC 3.2.1.23) activity (IU/g mucosal wet weight) in the mucosal tissue of the small intestine of pigs of different ages. Points are means, with their pooled standard errors represented by vertical bars, for four replicates. Treatments: $(\bigcirc)$, control; $(\square)$, probiotic; $\nabla)$, tylosin; for details of dietary treatments, see Table 1 and p. 60.

the preweaned than the post-weaning period studied. In contrast the activity of sucrase was significantly lower in the preweaned animals $(P<0 \cdot 001)$. There was no effect of age on tripeptidase activity. There were significant interactions between treatment and age in the tissues studied showing that the change in activity between pre- and post-weaned animals was less in the control group than in either the tylosin and Probios treatment groups for dipeptidase and lactase $(P<0.01)$. In addition, for lactase the change from pre- to postweaning was greater in the tylosin treatment group than the Probios treatment group $(P$ $<0.05$ ). Conversely for sucrase the pre- to post-weaning change was greater in tissues from control pigs than the tylosin and Probios treatment groups $(P<0.05)$. The change with tylosin was also significantly less than that in the Probios-treated animals $(P<0.05)$. There were no significant interactions between treatment and age for tripeptidase activity.

The results of the statistical analysis of data from each age of pig studied are shown in Table 5. At day 7 there was no significant effect of treatment on any of the enzymes studied. 


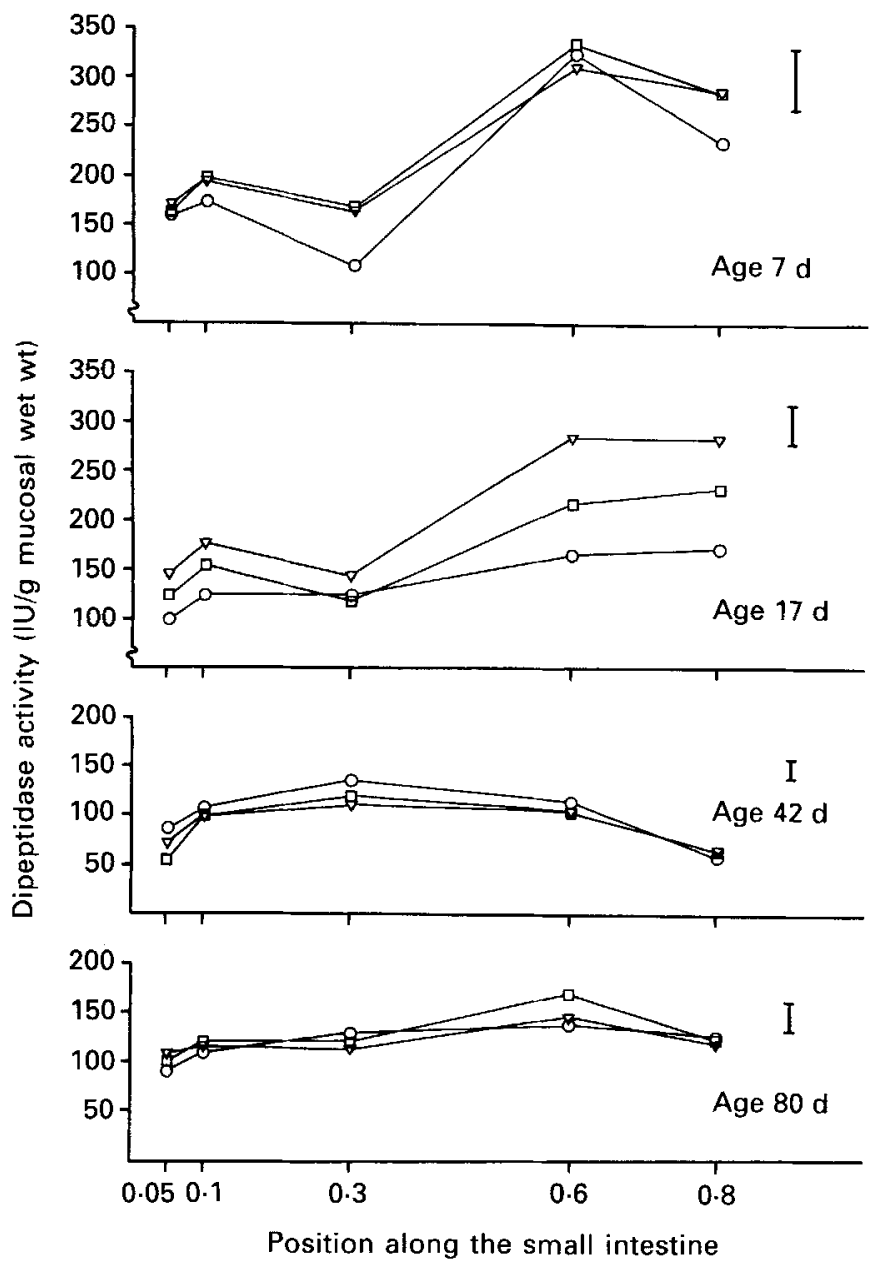

Fig. 3. The distribution of dipeptidase (EC 3.14.13.11, substrate L-leucylglycine) activity (IU/g mucosal wet weight) in the mucosal tissue of the small intestine of pigs of different ages. Points are means, with their pooled standard errors represented by vertical bars, for four replicates. Treatments : $(\bigcirc)$, control; $(\square)$, probiotic; $(\nabla)$, tylosin; for details of dietary treatments, see Table 1 and p. 60.

There was, however, an effect of site in the intestine, the activity in the proximal sites being significantly higher than the distal sites for sucrase $(P<0.001)$ and lower for dipeptidase and tripeptidase $(P<0.001)$. At day 17 tissues from control animals had significantly lower lactase, sucrase and tripeptidase activities than did tissues from the tylosin and Probios treatment groups (sucrase $P<0.001$, lactase $P<0.01$, tripeptidase $P<0.05$ ). In addition, for lactase and sucrase the activity in tissues from the Probios treatment group was significantly lower than that in the tylosin treatment group (lactase $P<0.01$, sucrase $P<$ $0-05$ ). For all enzymes measured there was a significant effect of site on activity at day 17 , with activity higher in the proximal sites than the distal ones for sucrase and lactase $(P<$ $0 \cdot 001)$ and lower at these sites for dipeptidase $(P<0.001)$ and tripeptidase $(P<0 \cdot 05)$. Analysis of the interaction between site and diet on day 17 showed that for sucrase, dipeptidase and tripeptidase the difference between the activity in the proximal and distal 


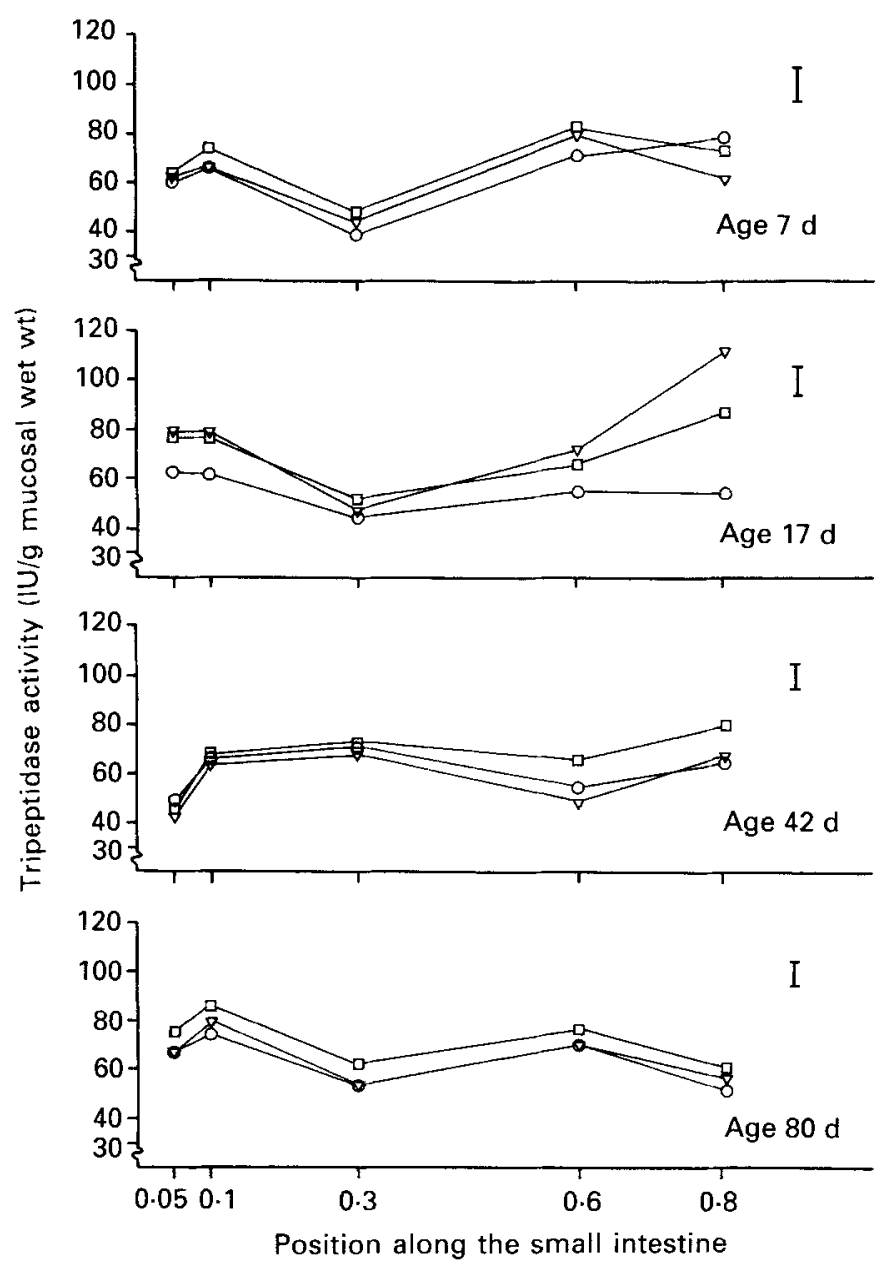

Fig. 4. The distribution of tripeptidase (EC 3.4.11.4, substrate L-leucylglycylglycine) activity (IU/g mucosal wet weight) in the mucosal tissue of the small intestine of pigs at different ages. Points are means, with their pooled standard errors represented by vertical bars, for four replicates. Treatments: $(\bigcirc)$, control; $(\square)$, probiotic; $(\nabla)$, tylosin; for details of dietary treatments, see Table 1 and p. 60.

sites was greater in the Probios- and tylosin-treated animals when compared with the control group (sucrase $P<0.01$, dipeptidase and tripeptidase $P<0.05$ ). There was no interaction between these two variables for the lactase activity measured.

At day 42 the only effect of treatment on the enzyme activities measured related to sucrase and lactase activities; activity in the tylosin-treated group being significantly lower than that in the Probios-treated group $(P<0.05)$ for sucrase, whereas for lactase the activity in control animals was higher than both the tylosin and Probios treatment groups $(P<0.05)$. At this age sucrase activity at the proximal sites was significantly lower than in the distal section $(P<0.05)$; for lactase and dipeptidase this effect was reversed, with activity in the proximal section higher than that in the distal intestine $(P<0.001$ and $P<$ 0.05 respectively). At day 80 sucrase and dipeptidase activities were lower in the proximal sites than at the distal ones $(P<0.05, P<0.01$ respectively), and for lactase the proximal activity remained higher than the activity at the distal sites $(P<0.001)$. 
Table 4. Summary of the effect of treatment, age and treatment $\times$ age on enzyme activity in the small intestine of the pig summed across all intestinal sites

\begin{tabular}{|c|c|c|c|}
\hline Enzyme activity & Treatment $\dagger$ & Age & Treatment $\times$ age \\
\hline $\begin{array}{l}\text { Sucrase } \\
\quad(E C 3.2 .1 .48)\end{array}$ & NS & Pre $<$ Post ${ }^{* * *}$ & $\begin{array}{c}{\left[\text { Pre v. Post] }: \mathrm{C}>\mathrm{T}+\mathrm{P}^{*}\right.} \\
{[\text { Pre } v \text {. Post }]: \mathrm{T}<\mathrm{P}^{*}}\end{array}$ \\
\hline $\begin{array}{l}\text { Lactase } \\
(E C \text { 3.2.1.23) }\end{array}$ & NS & Pre $>$ Post ${ }^{* * *}$ & $\begin{array}{c}\text { [Pre v. Post]: C }<\mathrm{T}+\mathrm{P}^{* *} \\
{\left[\text { Pre v. Post]: } \mathrm{T}>\mathrm{P}^{*}\right.}\end{array}$ \\
\hline $\begin{array}{l}\text { Dipeptidase } \\
(E C 3.14 .13 .11)\end{array}$ & NS & Pre $>$ Post*** & [Pre v. Post]: C $<\mathrm{T}+\mathrm{P}^{* *}$ \\
\hline $\begin{array}{l}\text { Tripeptidase } \\
(E C \text { 3.4.11.4) }\end{array}$ & NS & NS & NS \\
\hline
\end{tabular}

Treatment: C, basal diet; T, basal diet + tylosin $(40 \mathrm{mg} / \mathrm{kg}) ;$ P, basal diet + Probios; age: Pre, activity in preweaned pigs ( 7 and $17 \mathrm{~d}$ of age); Post, activity in post-weaned pigs ( 42 and $80 \mathrm{~d}$ of age); NS, not significant. ${ }^{*} P<0.05 ; * * P<0.01 ; * * * P<0.001$.

$\dagger$ For details of dietary treatments, see Table 1 and p. 60 .

Table 5. Summary of effect of treatment, site and treatment $\times$ site interaction on enzyme activity in the small intestine of pigs at $7,17,42$ and $80 \mathrm{~d}$ of age

\begin{tabular}{|c|c|c|c|c|}
\hline Age (d) ... & 7 & 17 & 42 & 80 \\
\hline \multicolumn{5}{|l|}{$\begin{array}{l}\text { Sucrase } \\
(E C \text { 3.2.1.48) }\end{array}$} \\
\hline Treatment & NS & $\begin{array}{l}\mathrm{C}<\mathrm{T}+\mathrm{P}^{* * *} \\
\mathrm{~T}>\mathrm{P}^{*}\end{array}$ & $\mathrm{~T}<\mathrm{P}^{*}$ & NS \\
\hline $\begin{array}{l}\text { Site } \\
\text { Site } \times \text { treatment }\end{array}$ & $\begin{array}{c}\text { Prox }>\text { Dist*** } \\
\text { NS }\end{array}$ & $\begin{array}{l}\text { Prox }>\text { Dist } * * * \\
{[\text { Prox } v \text {. Dist] }} \\
\mathrm{C}<\mathrm{T}+\mathrm{P}^{* *}\end{array}$ & $\begin{array}{c}\text { Prox }<\text { NS } \\
\text { Dist*** }\end{array}$ & $\begin{array}{c}\text { Prox }<\text { Dist } \\
\text { NS }\end{array}$ \\
\hline \multicolumn{5}{|l|}{$\begin{array}{l}\text { Lactase } \\
(E C 3.2 .1 .23)\end{array}$} \\
\hline Treatment & NS & $\begin{array}{l}\mathrm{C}<\mathrm{T}+\mathrm{P}^{* *} \\
\mathrm{~T}>\mathrm{P} * * *\end{array}$ & $\mathrm{C}>\mathrm{T}+\mathrm{P}^{*}$ & NS \\
\hline $\begin{array}{l}\text { Site } \\
\text { Site } \times \text { treatment }\end{array}$ & $\begin{array}{l}\text { NS } \\
\text { NS }\end{array}$ & $\begin{array}{c}\text { Prox }>\text { Dist } \\
\text { NS }\end{array}$ & $\begin{array}{c}\text { Prox }>\text { Dist } \\
\text { NS }\end{array}$ & $\begin{array}{c}\text { Prox }>\text { Dist }^{* * * *} \\
\text { NS }\end{array}$ \\
\hline \multicolumn{5}{|l|}{$\begin{array}{l}\text { Dipeptidase } \\
(E C 3.14 .13 .11)\end{array}$} \\
\hline Treatment & NS & NS & NS & NS \\
\hline $\begin{array}{l}\text { Site } \\
\text { Site } \times \text { treatment }\end{array}$ & $\begin{array}{c}\text { Prox }<\text { Dist } \\
\text { NS }\end{array}$ & $\begin{array}{l}\text { Prox }<\text { Dist }{ }^{* * *} \\
{[\text { Prox } v \text {. Dist }]} \\
\mathrm{C}<\mathrm{T}+\mathrm{P}^{*}\end{array}$ & $\begin{array}{c}\text { Prox > Dist* } \\
\text { NS }\end{array}$ & $\begin{array}{c}\text { Prox }<\text { Dist** } \\
\text { NS }\end{array}$ \\
\hline \multicolumn{5}{|l|}{$\begin{array}{l}\text { Tripeptidase } \\
(E C 3.4,11.4)\end{array}$} \\
\hline Treatment & NS & $\mathrm{C}<\mathrm{T}+\mathrm{P}^{*}$ & NS & NS \\
\hline Site & Prox $<$ Dist*** & Prox $<$ Dist $^{*}$ & NS & NS \\
\hline Site $\times$ treatment & NS & $\begin{array}{l}\text { [Prox v. Dist]: } \\
\mathrm{C}<\mathrm{T}+\mathrm{P}^{*}\end{array}$ & NS & NS \\
\hline
\end{tabular}

Treatment: $C$, basal diet; $T$, basal diet + tylosin $(40 \mathrm{mg} / \mathrm{kg}) ; \mathrm{P}$, basal diet + Probios; site: Prox, activity in proximal sites $(0 \cdot 05,0 \cdot 1+0 \cdot 3)$; Dist, activity in distal sites $(0 \cdot 6+0 \cdot 8)$; NS, not significant.

${ }^{*} P<0.05 ;{ }^{* *} P<0.01 ;{ }^{* * *} P<0.001$.

$\dagger$ For details of dietary treatments, see Table 1 and p. 60 . 


\section{DISCUSSION}

The results from the present experiment provide information as to the development of enzyme activity along the intestine of the pig from $7 \mathrm{~d}$ of age to $80 \mathrm{~d}$ of age and the influence manipulation of the intestinal microflora has on this process. The effect of age and position along the intestine of pigs on the activity of carbohydrase enzymes has been studied by a number of authors (Manners \& Stevens, 1972; Stevens \& Kidder, 1972; Kidder \& Manners, 1976, 1978, 1980; McCracken, 1984; McCracken \& Kelly, 1984), although in most cases it has been the effect of weaning that has been of primary interest. It is apparent from the findings presented here that the activity of individual enzymes is dependent on both age and site within the gastrointestinal tract. Sucrase activity (Fig. 1) was well established in mucosal tissue by $7 \mathrm{~d}$ of age with the sites of highest activity being in the proximal part of the intestine. The time intervals of sampling used precluded examination of the temporary decline in activity of this enzyme over the immediate post-weaning period (Hampson \& Kidder, 1986), but it is apparent that the activity had been re-established by day 42 and that at both the post-weaning time intervals studied the sites of maximal enzyme activity had shifted to the distal portion of the intestine. Lactase activity (Fig. 2) was evenly distributed throughout the intestine of all piglets at $7 \mathrm{~d}$ of age although by day 17 in two of the treatment groups (tylosin and Probios) activity in the proximal intestine appeared to be higher than that measured at the distal sites. In agreement with previous studies (Hampson \& Kidder, 1986) lactase activity declined after weaning as substrate supply ceases although at both later sampling times there was a distinctive pattern of enzyme activity in the mucosa, proximal sites maintaining a higher activity than distal ones.

The development of peptide hydrolases with age and site in the intestine of pigs (Figs. 3 and 4) shows that mucosal dipeptidase activity was higher overall in the preweaning period than post-weaning. At days 7 and 17 activity was higher in the distal intestine than at the proximal sites, and after weaning the pattern of activity was more uniform throughout the gut. Ability to hydrolyse the tripeptide substrate was also well developed by $7 \mathrm{~d}$ of age, although it was only in the preweaning period that a significant difference between the proximal and distal sections of the intestine was apparent. Studies of the distribution of a range of peptide hydrolases in sheep (Richardson \& Jouan, 1986) and the pig (Josefsson \& Lindberg, 1965) showed that in the mature animals highest activity was associated with the ileum $(0.5-0.7$ of intestinal length). Studies of the distribution of the enzymes between the cytosolic and brush border fractions of the cell indicated that while the dipeptidase was primarily a cytosolic enzyme, a significant percentage (64) of the tripeptidase activity was located in the brush border fraction of sheep tissues (Richardson \& Jouan, 1986).

Manipulation of the growth rates of pigs in commercial practice has been successfully achieved by the use of a range of antimicrobial growth promoters which act within the intestinal tract (for review, see Rosen, 1984). In the present experiment inclusion of either an antibiotic (tylosin) or a probiotic (Probios) in the basal diet resulted in an improvement in growth performance (Collington et al. 1988). Both these treatments also had effects on the development of digestive enzyme function within the intestinal mucosa which were, in general, more significant in the preweaning than in the post-weaning period. In the case of the carbohydrase enzymes, inclusion of either the antibiotic or probiotic resulted in significantly higher enzyme activities in the mucosal tissue when compared with the control group at day 17 after the piglets had had access to the creep feed for $10 \mathrm{~d}$. This stimulation of enzyme activity was at the proximal site in the intestine and in the case of lactase there was a differential effect between the two treatments, activity as a result of tylosin treatment being higher than that determined in the Probios group. 
The only overall treatment effect on the activity of the two peptide hydrolases measured was that of tripeptidase in tissues from pigs sampled on day 17 in which activity in the control group was significantly lower than that measured in the Probios and tylosin animals $(P<0.05)$. This enzyme, in common with the two carbohydrases measured, is primarily located in the brush border of the enterocyte cell whereas the majority of the dipeptidase activity is cytosolic (Peters, 1970, 1977).

These findings support the hypothesis that the microbial population of the gastrointestinal tract has a major influence in the modulation of enterocyte activity and expression of tissue function. Studies in conventional and germ-free pigs (Szabo, 1979) have shown an increase in both carbohydrase and peptidase activities in duodenal and ileal tissue from germ-free pigs and this observation has also been made for the carbohydrase enzymes in germ-free chicks (Siddons \& Coates, 1972). In healthy animals stress, as a result of starvation, has been shown to result in change in the microbial flora of the small intestine in pigs (Chopra et al. 1963; Morishita \& Ogata, 1970) and chickens (Smith, 1965) and similar effects occur at weaning (Barrow et al. 1977). These changes are associated with modification in the histology of the intestine indicating an increase in the rate of cell migration up the villus surface. Findings from Smith (1984), Miller et al. (1986) and Hampson \& Smith (1986) clearly identify change in the absorptive capacity of the intestine at the time of weaning as being linked with the variations in cell migration rate and enterocyte maturation on the villus surface. In the present experiment, inclusion of either a probiotic or antibiotic preparation has influenced the development of enzyme activity in the mucosal tissue. This is most apparent at day 17 when the piglets had had access to the creep feed for $10 \mathrm{~d}$. The increased expression of brush-border enzyme activity at this time in the two treatment groups when compared with control animals may reflect an increased proportion of mature cells on the villi as a result of lower cell turnover in the intestinal tissue at this period immediately before weaning (Miller et al. 1986). The growth performance of the three groups of pigs in the present study suggests that these changes may mitigate the effect of weaning on intestinal function and subsequent growth in the young pig.

The authors are grateful to Dr P. Avery for his help with the statistical analysis of the data and to Pioneer Hi-Bred International Inc. for financial support.

\section{REFERENCES}

Armstrong, D. G. (1984). Antibiotics as feed additives for ruminant livestock. In Antimicrobials in Agriculture, pp. 331-347 [M. Woodbine, editor]. London: Butterworths.

Armstrong, D. G. (1986). Gut active growth promoters. In Control and Manipulation of Animal Growth, Proceedings of the University of Nottingham 43rd Easter School, 1985, pp. 21-37 [P. J. Buttery, D. Lindsay and N. B. Haynes, editors]. London: Butterworths.

Badaway, A. M., Campbell, R. M., Cuthbertson, D. P. \& Fell, B. F. (1957). Changes in the intestinal mucosa of the sheep following death by humane killer. Nature 183, 756-757

Baker, R. J. \& Nelder, J. A. (1978). Glim System Release 3. Oxford: Numerical Algorithms Group.

Barrow, P. A., Fuller, R. \& Newport, M. J. (1977). Changes in the microflora and physiology of the anterior intestinal tract of pigs weaned at 2 days, with special reference to pathogenesis of diarrhea. Infection and Immunity 18, 586-595.

Brander, G. C. (1986). Chemicals for Animal Health Control. London: Taylor and Francis Ltd.

Braude, R. (1967). Copper as a growth stimulant in pigs. Animal Production 3, 69-75.

Chopra, S. L., Blackwood, A. C. \& Dale, D. G. (1963). Intestinal microflora associated with enteritis in early weaned pigs. Canadian Journal of Comparative Medicine 27, 290-294.

Collington, G. K., Parker, D. S., Ellis, M. \& Armstrong, D. G. (1988). The influence of Probios or Tylosin on growth of pigs and development of the gastrointestinal tract. Animal Production 46, 521-522.

Dahlquist, A. (1964). Method for assay of intestinal disaccharidases. Analytical Biochemistry 7, 18-25.

Hampson, D. J. \& Kidder, D. E. (1986). Influence of creep feed and weaning on brush border enzyme activities in the piglet small intestine. Research in Veterinary Science 40, 24-31. 
Hampson, D. J. \& Smith, W. C. (1986). Influence of creep feeding and dietary intake after weaning on malabsorption and occurrence of diarrhoea in the newly weaned pig. Research in Veterinary Science 41, 63-69.

Josefsson, L. \& Lindberg, T. (1965). Intestinal dipeptidases. 11. Distribution of dipeptidases in the small intestine of the pig. Biochimica et Biophysica Acta 105, 162-166.

Kidder, D. E. \& Manners, M. J. (1976). Carbohydrases in the small intestine mucosa of the pig. Proceedings of the Nutrition Society 35, 26A.

Kidder, D. E. \& Manners, M. J. (1978). Carbohydrases in the small intestine mucosa of sow-reared and 3-week weaned piglets. Proceedings of the Nutrition Society 37, $51 \mathrm{~A}$.

Kidder, D. E. \& Manners, M. J. (1980). The level and distribution of carbohydrases in the small intestine mucosa of pigs from 3 weeks of age to maturity. British Journal of Nutrition 43, 141-153.

McCarthy, D. M. \& Kim, Y. S. (1973). Changes in sucrase, enterokinase and peptide hydrolase after intestinal resection. The association of cellular hyperplasia and adaption. Journal of Clinical Investigation 52, 942-951.

McCracken, K. J. (1984). Effect of diet composition on digestive development of early-weaned pigs. Proceedings of the Nutrition Society 43, 109A.

McCracken, K. J. \& Kelly, D. (1984). Effect of diet and post-weaning food intake on digestive development of early-weaned pigs. Proceedings of the Nutrition Society 43,110A.

Manners, M. J. \& Stevens, J. A. (1972). Changes from birth to maturity in the pattern of distribution of lactase and sucrase activity in the mucosa of the small intestine of pigs. British Journal of Nutrition 28, $113-127$.

Metchnikoff, E. (1908). Prolongation of Life. New York: G. P. Putnam and Sons.

Miller, B. G., James, P. S., Smith, M. W. \& Bourne, F. J. (1986). Effect of weaning on the capacity of pig intestinal villi to digest and absorb nutrients. Journal of Agricultural Science, Cambridge 107, 579-589.

Morishita, Y. \& Ogata, M. (1970). Studies on the alimentary flora of pigs v. influence of starvation on the microbial flora. Japanese Journal of Veterinary Sciences 32, 19-24.

Nicholson, J. A. \& Kim, Y. S. (1975). A one-step L-amino acid oxidase assay for intestinal peptide hydrolase activity. Analytical Biochemistry 63, $110-117$.

Peters, T. J. (1970). The subcellular localization of di- and tripeptide hydrolase activity in guinea-pig small intestine. Biochemical Journal 120, 195-203.

Peters, T. J. (1977). Subcellular distribution of di- and tripeptidase in human jejunum. Clinical Science and Molecular Medicine 52, $16 \mathrm{P}$.

Richardson, R. I. \& Jouan, A. R. P. (1986). The distribution of peptidase activity in the small intestine of sheep. British Journal of Nutrition 55, 149-156.

Rosen, G. D. (1984). Performance promoters in animal nutrition: (ii) methods of comparison of effectiveness. In Antimicrobials and Agriculture, pp. 303-313 [M. Woodbine, editor]. London: Butterworths.

Siddons, R. C. \& Coates, M. (1972). The influence of the intestinal microflora on disaccharidase activities in the chick. British Journal of Nutrition 27, 101-112.

Schmitz, J., Preiser, H., Maestracci, D., Ghosh, B. K., Cerda, J. J. \& Crane, R. K. (1973). Purification of the human intestinal brush border membrane. Biochimica et Biophysica Acta 323, 98-112.

Smith, H. W. (1965). Observations on the flora of the alimentary tract of animals and factors affecting its composition. Journal of Pathology and Bacteriology 89, 95-122.

Smith, M.W. (1984). Effect of postnatal development and weaning upon the capacity of pig intestinal villi to transport alanine. Journal of Agricultural Science, Cambridge 102, 625-633.

Stevens, J. A. \& Kidder, D. E. (1972). The distribution of trehalase, sucrase, amylase, glucoamylase and lactase ( $\beta$-galactosidase) along the small intestine of five pigs. British Journal of Nutrition 28, 129-137.

Szabo, J. (1979). Protein, carbohydrate and fat degrading enzymes in the intestine of germ-free and conventional piglets. In Clinical and Experimental Gnotobiotics, p. 125 [T. Fliedner, H. Heit, D. Niethammer and H. Pflieger, editors]. Stuttgart and New York: Fischer Verlag.

Tannock, G. W. (1983). Effect of dietary and environmental stress on the gastrointestinal microbiota. In Human Intestinal Microfiora in Health and Disease, pp. 517-539 [D. J. Hertges, editor]. London: Academic Press.

Visek, W. J. (1978). The mode of growth promotion by antibiotics. Journal of Animal Science 46, 1447-1469. 